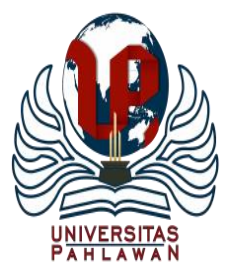

Edukatif : Jurnal Ilmu Pendidikan Volume 3 Nomor 5 Tahun 2021 Halm 2287 - 2298

EDUKATIF: JURNAL ILMU PENDIDIKAN

Research \& Learning in Education

https://edukatif.org/index.php/edukatif/index

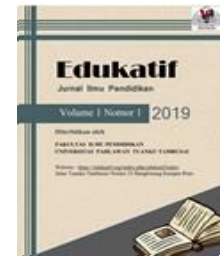

\title{
Analisis Kemampuan Membaca Pemahaman dalam Pembelajaran Multiliterasi Siswa Sekolah Dasar
}

\author{
Nova Mira Rizky Wulandari ${ }^{1 凶}$, Neneng Sri Wulan ${ }^{2}$, W Wahyudin ${ }^{3}$ \\ Universitas Pendidikan Indonesia, Indonesia ${ }^{1,2,3}$ \\ E-mail : $\underline{\text { novamira@upi.edu }}{ }^{1}, \underline{\text { neneng_sri_wulan@upi.edu }}{ }^{2},{\underline{\text { dwahyudin@ } @ u_{\text {upi.edu }}}}^{3}$
}

\begin{abstract}
Abstrak
Pembelajaran multiliterasi dalam membaca pemahaman merupakan integrasi pembelajaran literasi dan teknologi untuk meningkatkan pemahaman dan jawaban tuntutan pembelajaran abad 21 era digital. Kerjasama siswa, guru dan orang tua diperlukan untuk keberhasilan pembelajaran multiliterasi. Penelitian ini bertujuan mengetahui kemampuan, kendala dan solusi kemampuan membaca pemahaman dalam pembelajaran multiliterasi siswa kelas V SDN 3 Nagri Kaler, karena masih terdapat lima orang siswa yang belum memiliki kemampuan membaca pemahaman dalam pembelajaran multiliterasi. Dengan metode kualitatif pendekatan studi kasus, penemuan data melalui tes, wawancara, analisis data dan dokumentasi di SDN 3 Nagri Kaler pada bulan April-Juni. Subjek penelitian adalah lima orang siswa kelas V, lima orang tua siswa, guru, dan kepala sekolah. Hasil pemahaman literal (C1) 51,6\%, infensial (C2, C3) 35\%, kritis (C4,C5) 57,5\% dan kreatif (C6) $50 \%$, Nilai akhir tes $51 \%$ kategori kurang. Hasil wawancara menyatakan membaca pemahaman pembelajaran multiliterasi menyenangkan, memperoleh pengetahuan baru dan subjek mampu menggunakan teknologi. Kendala disebabkan faktor ekonomi keluarga dan kurangnya kesiapan guru dalam pembelajaran multiliterasi. Solusinya perkuat kerjasama siswa, orang tua dan pihak sekolah dalam memonitor dan memberi sarana bacaan sesuai minat siswa serta kemauan guru berlatih mengelola pembelajaran multiliterasi secara menerus.
\end{abstract}

Kata Kunci: Kemampuan Membaca Pemahaman, Pembelajaran Multiliterasi, Siswa Kelas V SD.

\begin{abstract}
Multiliteracy learning in reading comprehension is an integration of literacy learning and technology to improve understanding and answer the demands of 21st century learning in the digital era. Cooperation of students, teachers and parents is needed for the success of multiliteracy learning. This study aims to determine the abilities, constraints and solutions for reading comprehension skills in multiliteracy learning for fifth grade students at SDN 3 Nagri Kaler, because there are still five students who do not have the ability to read comprehension in multiliteracy learning. Using a qualitative case study approach, data were found through tests, interviews, data analysis and documentation at SDN 3 Nagri Kaler in April-June. The research subjects were five fifth grade students, five parents, teachers, and the principal. The result of literal understanding $(C 1)$ is $51.6 \%$, infensial $(C 2, C 3) 35 \%$, critical $(C 4, C 5) 57.5 \%$ and creative (C6) $50 \%$, the final test score is $51 \%$ in the poor category. The results of the interview stated that reading comprehension of multiliterate learning was fun, gaining new knowledge and the subject was able to use technology. Constraints are caused by family economic factors and the lack of teacher readiness in multiliterate learning. The solution is to strengthen collaboration between students, parents and schools in monitoring and providing reading facilities according to students' interests and the willingness of teachers to practice managing multiliteracy learning continuously.
\end{abstract}

Keywords: Reading Comprehension Ability, Multiliteracy Learning, V Grade Elementary School Students.

Copyright (c) 2021 Nova Mira Rizky Wulandari, Neneng Sri Wulan, D Wahyudin

$\triangle$ Corresponding author

Email : novamira@upi.edu

DOI : https://doi.org/10.31004/edukatif.v3i5.833

ISSN 2656-8063 (Media Cetak)

ISSN 2656-8071 (Media Online)

Edukatif : Jurnal Ilmu Pendidikan Vol 3 No 5 Tahun 2021 p-ISSN 2656-8063 e-ISSN 2656-8071 
2288 Analisis Kemampuan Membaca Pemahaman dalam Pembelajaran Multiliterasi Siswa Sekolah Dasar Nova Mira Rizky Wulandari, Neneng Sri Wulan, D Wahyudin

DOI: https://doi.org/10.31004/edukatif.v3i5.833

\section{PENDAHULUAN}

Pada era digital abad 21 dunia mengalami kemajuan teknologi yang modern termasuk dalam KBM yang terlihat dalam penyampaian latihan secara tidak langsung dengan akses internet (Youtube), Ruang tidak terbatas karena di ikuti secara online (Classroom), mejadi bebas kertas (Paperless) penggunaan akses internet dalam pengiriman jawaban sehingga peserta didik tidak perlu mecatat dan dapat di lihat secara berulang bahkan di download dan jawaban setiap tugas tidak memerlukan banyak kertas, cukup mengetik dan mengirim foto pada kolom jawaban di platform yang tersedia (Classroom, Whatsaap, Google formulir). Fasilitas fisik menjadi akses jaringan, durasi waktu lebih cepat Rosenberg (Subroto, 2015). Akses internet digunakan juga dalam pembelajaran bahasa Indonesia pada kegiatan membaca pemahaman sebagai kegiatan yang dapat dilakukan dimanapun dan kapanpun saat belajar ataupun sebelum belajar Adhitiya dalam (Chrismawati et al., 2021) dilakukan secara natural manusia dan benda yang saling terkait (Madyawati, 2017). Untuk memperoleh kecakapan dalam diri agar dapat berfikir secara kritis dapat terlihat dari kemampuan peserta didik dalam mendapatkan, mengidentifikasi, mengkalsifikasi, mengakses, menemukan, mengevaluasi dan memanfaatkan informasi secara efektif, etis dan efisien (Khairil, 2020).

Adanya konsep pembelajaran multilitasi yang mengintegrasikan berbagai akses media dan teknologi untuk mengantarkan informasi (Saputro et al., 2021) yang sesuai dengan situasi lingkungan siswa serta jalan tengah untuk regulasi satuan pendidikan era digital abad 21 (Abidin et al., 2018) yang menuai dukungan UU No.20 Tahun 2003 tentang Sistem pendidikan nasional Pasal 1 No. 19 Pembelajaran adalah proses interaksi antar peserta didik, antara peserta didik dengan pendidik dan sumber belajar pada suatu lingkungan belajar, Pasal 2 ayat 3 Standar Nasional Pendidikan disempurnakan secara terencana, terarah, dan berkelanjutan sesuai dengan tuntutan perubahan kehidupan lokal, nasional, dan global. Penerapan multiliterasi di era digital dimana peserta didik harus menggunakan teknologi, kegiatan membaca merupakan usaha sadar oleh peserta didik untuk menuai, mengelola, dan menggunakan informasi dari penulis yang di sampaikan melalui media atau bahasa tertulis (Susilo \& Garnisya, 2018), untuk siswa kelas tinggi $(4,5,6)$ telah berkopeten dalam teks panjang (150-200 kata) dan memiliki kopetensi untuk meminta peserta didik dalam membaca pemahaman. kelas rendah $(1,2,3)$ hanya membaca teks pendek ( $<150$ kata) dengan berbagai simbol, gambar yang menarik (Pratama, 2015).

Untuk mengetahui tingkat perkembangan kemampuan membaca peserta didik, terdapat PISA untuk penilaian peserta didik skala Internasional berupa integrasi berbagai faktor dalam kegiatan literasi, proses pembelajaran, karakteristik sekolah, struktur pelaksanaan organisasi dalam KBM dan SDM untuk menyukseskan pendidikan (OEDC, 2003). Tahun 2012 dalam (Pulungan, 2015) melalui Education For All Global Monitoring Report memberikan data faktual kemampuan peserta didik Indonesia di pringkat 64 dari 120 negara di seluruh dunia, tahun 2011 Indeks Perkembangan Pendidikan EDI mencatat Indonesia berada di peringkat ke-69 dari 127 negara, PIRLS memberikan data faktual stratifikasi pada kemampuan literacy (membaca) Indonesia menduduki rangking 41 dari 45 negara, dapat disimpulkan Indonesia mengalami krisis kemampuan dalam literacy (membaca).

Berdasarkan tinjauan empiris terdapat tiga penelitian terdahlu yang membahas tentang kemampuan membaca pemahaman dalam pembelajaran multiliterasi penelitian pertama berjudul model pembelajaran multiliterasi pada pembelajaran membaca pemahaman di kelas IV SDIT Baitul Jannah School kota Bandar Lampung oleh (Ristika, 2019). Menuai hasil bahwa model pembelajaran multiliterasi dapat meningkatkan kemampuan membaca pemahaman siswa kesamaan dari penelitian ini terkait dengan kemampuan membaca pemahaman dan proses pembelajaran multiliterasi dan terdapat perbedaan pada jenis metode penelitian yakni Penelitian tindakan kelas, penelitian kedua berjudul implementasi model multiliterasi pada proses pembelajaran membaca pemahaman siswa kelas IV SDN 04 Andaleh Kecamatan Luhak oleh (Dafit, 2017), menuai hasil pembelajaran multiliterasi mampu meningkatkan kemampuan siswa dalam memahami bacaan. 
Kesamaan dari penelitian ini terkait dengan kemampuan membaca pemahaman yang menggunakan pembelajaran multiliterasi dan terdapat perbedaan pada jenis penelitian kuantitatif dengan metode quasi experiment. Penelitian ketiga berjudul penerapan model multiliterasi untuk meningkatkan kemampuan membaca Pemahaman siswa kelas V SDN Trajaya III oleh (Susilo \& Garnisya, 2018) dengan 3 siklus, menuai hasil siklus I dengan proses pembelajaran yang kurang efektif karena tiada bantuan media sehingga hasil kurang baik, siklus II guru dibantu dengan media pembelajaran sehingga hasil cukup baik, siklus III menggunakan model multiliterasi rata-rata nilai proses membaca pemahaman sehingga memperoleh hasil sangat baik. Hasil ketiga penelitan terdahulu menyatakan model pembelajaran multiliterasi dapat meningkatkan kemampuan membaca pemahaman siswa pernyataan tersebut telah dibahas dalam wujud penelitian kuantitaif dengan pendekatan tindakan kelas dan quasi eksperimen sehingga belum adanya pembahasan dalam penelitian kualitatif dengan pendekatan sudi kasus.

Namun berdasarkan hasil pengalaman observasi peneliti di kelas V SDN 3 Nagri Kaler pada materi Bahasa Indonesia terdapat beberapa peserta didik yang mengalami kesulitan memahami isi teks bacaan saat kegiatan membaca pemahaman dalam pembelajaran multiliterasi yang telah diterapkan oleh tenaga pendidik (guru) di era digital, dimana guru mengelola, mengajar, dengan cara mengirimkan video pembelajaran bersumber dari Youtube, untuk mengefektifkan pembelajaran dan beberapa siswa masih mengalami kesulitan dalam memahami bacaan baik dalam pemahaman literal, inferensial, kritis, dan kreatif. Sehingga sangat berbeda dengan hasil yang dilakukan oleh sebelumnya oleh (Ristika, 2019), (Dafit, 2017) dan (Susilo \& Garnisya, 2018). Melalui latar belakang tersebut sangat perlunya penelitian yang berjudul analisis kemampuan membaca pemahaman dalam pembelajaran multiliterasi siswa sekolah dasar di kelas V SDN 3 Nagri Kaler sebagai penelitian metode kualitatif dengan pendekatan studi kasus sehingga penelitian ini memiliki perberbedan dengan penelitian yang telah dilakukan sebelumnya. Penelitian ini dibatasi pembahasannya hanya untuk mengetahui bagaimana kemampuan membaca pemahaman dalam pembelajaran multiliterasi siswa kelas V SDN 3 Nagri Kaler, apa kendala kemampuan membaca pemahaman dalam pembelajaran multiliterasi siswa kelas V SDN 3 Nagri Kaler, dan bagaimana solusi mengatasi kendala kemampuan membaca pemahaman dalam pembelajaran multiliterasi siswa kelas V SDN 3 Nagri Kaler.

Menggunakan teori tingkatan pemahaman menurut Burns dan Roes dalam (Dalman, 2021) yakni literal adanya pengunaan 5W+1H Burn, Roe dan Ross (Dalman, 2021), interpretatif kemampuan berpikir lebih tinggi karena jawaban tidak ada dalam teks melainkan pendapat dari peserta didik itu sendiri Burns, Rubin (1982) dalam (Fauziah, 2013), kritis melalui integrasikan pengalaman terhadap pemahaman yang baru untuk mengiktisar kemudian menilai hasil bacaan syafi'i 1993 dalam (Rahim, 2018) dan kreatif berupa penyajian satra dengan bentuk lainnya seperti Mind mapping merupakan suatu karya imajinatif yang efektif untuk memunculkan kreatifitas siswa Tony Buzan (2009) dalam (Aprinawati, 2018). Teori kategori dan dimensi proses kognitif yang terkenal dengan istilah C1-C6 taksonomi Bloom Anderson dan Krathwohl (2001) dalam (Abidin, 2016) juag digunakan untuk membaca pemahaman sebagai proses kesungguhan peserta didik memperoleh informasi (Abidin, 2012). Kemampuan pemahaman membaca merupakan faktor utama untuk memahami informasi dan menerapkan informasi dalam kehidupan sehari-hari Hall dalam (Fauzi, 2020) secara multi ability Graesser dalam Kondeou dalam (Fauzi, 2020). Terdapat berbagai faktor yang mempengaruhi kemampuan siswa salah satunya fisiologis (gangguan pendengaran, pengelihatan, bicara) dan terdapat juga gejala kesulitan belajar dalam membedakan lambang bacaan berupa; huruf, angka, kata. Lamb dan Arnold (1976) dalam (Rahim, 2018). Perkembangan fisik siswa dipengaruhi oleh berbagai faktor: 1) Keturunan genetik, 2) Konsumsi panganan, 3) Kedisiplinan dalam berlatih keterampilan peserta didik diperlukan dalam proses membaca untuk melatih kefasihan diri dan fokus pembaca Dalman dalam (Untari \& Saputra, 2016)., 4) rutinitas, 5) Kondisi lingkungan. Faktor Intelektual, Faktor Lingkungan meliputi: 1) Latar belakang dan pengalaman peserta didik di rumah, 2) Sosial ekonomi keluarga peserta didik. Faktor psikologis meliputi: 1) Motivasi, 2) Minat (Danim, 2017). Peran teknologi merupakan suatu keniscayaan, guru dan siswa 
2290 Analisis Kemampuan Membaca Pemahaman dalam Pembelajaran Multiliterasi Siswa Sekolah Dasar Nova Mira Rizky Wulandari, Neneng Sri Wulan, D Wahyudin

DOI: https://doi.org/10.31004/edukatif.v3i5.833

menggunakan komunikasi digital berupa media elektronik untuk mengefektifkan interaksi dalam KBM, (Haryoko, 2009) dalam (Bahtiar, 2016) dan guru dapat menggunakan akses internet, berupa audio visual, teks untuk pelajaran membaca sejarah (Iswara, 2016). Pemahaman hadir dengan pembiasaan terlatih secara berkesinambungan dan memerlukan berbagai dukungan Bunanta dalam (Saleh, 2006), Wolley dalam (Abidin, 2015) adanya multiliterasi dalam pembelajaran membaca dapat meningkatkan kemampuan siswa dalam memahami teks bacaan dengan pemanfaatan beragam teknologi melalui tiga proses yaitu: aktivitas pramembaca dengan skemata mengkonstruksi pengetahuan dan informasi dasar untuk memberikan respon gagasan dan informasi dari teks bacaan dengan acuan kata tanya $5 \mathrm{~W}+1 \mathrm{H}$ (Fuady et al., 2012), aktivitas membaca terdapat kemampuan literal, inferensial, kritis, aktivitas pasca membaca dengan merespon pemahaman dengan berbagai media representasi Berger dan Lapp dalam (Abidin, 2015). Kelas 4,5,6 temasuk dalam level membaca mandiri Fountas dan Pinnell Fountas dan Pinnel (2008) dalam (Abidin, 2015).

\section{METODE PENELITIAN}

Penelitian ini menggunakan pendekatan studi kasus untuk mengkaji lebih dalam seseorang atau kelompok yang memiliki kasus tertentu (Salim \& Haidir, 2019) dengan metode kualitatif yang bersifat naturalistik Sujana (1989) dalam (Rukajat, 2018) untuk menghasilkan teori mendalam, berdasarkan survei (Sugiyono, 2016) dengan teknik mengumpulkan data dengan memberikan tes, wawancara untuk menganalisis kemampuan membaca pemahaman dalam pembelajaran multiliterasi siswa yang merupakan metode guru kelas untuk mngoptimalkan KBM (Mariyaningsih \& Hidayai, 2018) dengan jumlah subjek yang dekat dengan peneliti kualitatif (Sugiyono, 2016) dan kaya deskripsi dan informasi Guetterman dalam (Marzoan, 2020) sampel di pilih berdasarkan pertimbangan tertentu, pertimbangan yang diambil adalah 1. Lokasi jarak yang memungkinkan akses mudah 2. Lima peserta didik SD kelas V dengan jenis kelamin laki-laki berjumlah dua orang DF, OZ, dan jenis kelamin perempuan berjumlah tiga orang AI, AN, MR. 3. Kelima peserta didik memiliki kesulitan membaca pemahaman dalam pembelajaran multiliterasi dan bersedia untuk dianalisis kemampuan membaca pemahamannya 4. Guru kelas V SD, 5 Orang tua murid peserta didik kelas V SD yang dilaksanakan selama bulan April-Juni 2021, (Saripudin et al., 2019) pengumpulan data adalah langkah paling strategis dan tujuan utama dari penelitian. Guest et al., (2006); Krysik \& Finn, (2010) dalam (Purwanto et al., 2020) menyatakan bahwa proses penelitian studi kasus terdapat kegiatan wawancara kepada responden yaitu kelima siswa, orang tua, guru dan kepala sekolah untuk menemukan informasi yang mencapai saturasi hingga tidak ada informasi lainnya. Penelitian kualitatif dilakukan secara langsung kepada subjek dengan pemberian tes kemampuan membaca pemahaman dalam pembelajaran mulititerasi siswa kelas V Bogdan dan Biklen (1982) dalam (Sugiyono, 2016) dan (Hasan, 2015) untuk mengukur kemampuan pemahaan literal, inferensial/interpretatif, kritis, kreatif sesuai Anderson dan Krathwohl (2001) dalam (Abidin, 2016) dan kata kerja operasional domain kognitif Morrison (2011) dalam (Abidin, 2016)

Tabel 1. Indikator Tes Kemampuan Membaca Pemahaman dalam Pembelajaran Multiliterasi

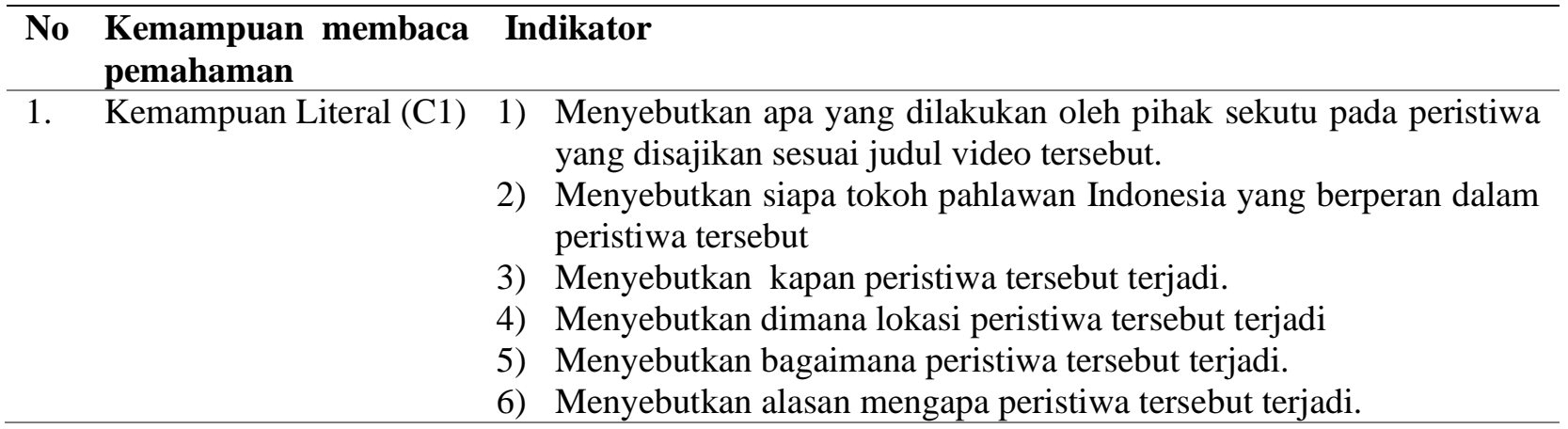


2291 Analisis Kemampuan Membaca Pemahaman dalam Pembelajaran Multiliterasi Siswa Sekolah Dasar Nova Mira Rizky Wulandari, Neneng Sri Wulan, D Wahyudin

DOI: https://doi.org/10.31004/edukatif.v3i5.833

\begin{tabular}{lll}
\hline $\begin{array}{l}\text { Kemampuan } \\
\text { Inferensial/Interpretatif } \\
(\mathrm{C} 2, \mathrm{C} 3)\end{array}$ & 7) & $\begin{array}{l}\text { Menceritakan kembali peristiwa tersebut dan nilai moral yang dapat } \\
\text { diteladani dengan bahasa sendiri secara tertulis. }\end{array}$ \\
\hline 3. $\begin{array}{l}\text { Kemampuan Kritis } \\
(\mathrm{C} 4, \mathrm{C} 5)\end{array}$ & 8) $\begin{array}{l}\text { Membuat sketsa wajah tokoh yang dikagumi dan menuliskan } \\
\text { bagian menarik dari peristiwa } \\
\text { Membuat suatu diagram venn yang berisi perbandingan sifat yang } \\
\text { dimiliki tokoh utama dengan anda }\end{array}$ \\
& $\begin{array}{l}\text { Kemampuan Kreatif } \\
\text { (C6) }\end{array}$ \\
\hline
\end{tabular}

Tabel 2. Bahan Ajar Penelitian Kemampuan Membaca Pemahaman dalam Pembelajaran Multiliterasi

\begin{tabular}{llllll}
\hline $\begin{array}{l}\text { Thumbnail } \\
\text { Video }\end{array}$ & $\begin{array}{l}\text { Judul } \\
\text { Video }\end{array}$ & $\begin{array}{l}\text { Fokus } \\
\text { pemahaman }\end{array}$ & $\begin{array}{l}\text { Kategori dimensi } \\
\text { kognitif }\end{array}$ & Indikator & $\begin{array}{l}\text { Bentuk } \\
\text { soal }\end{array}$
\end{tabular}

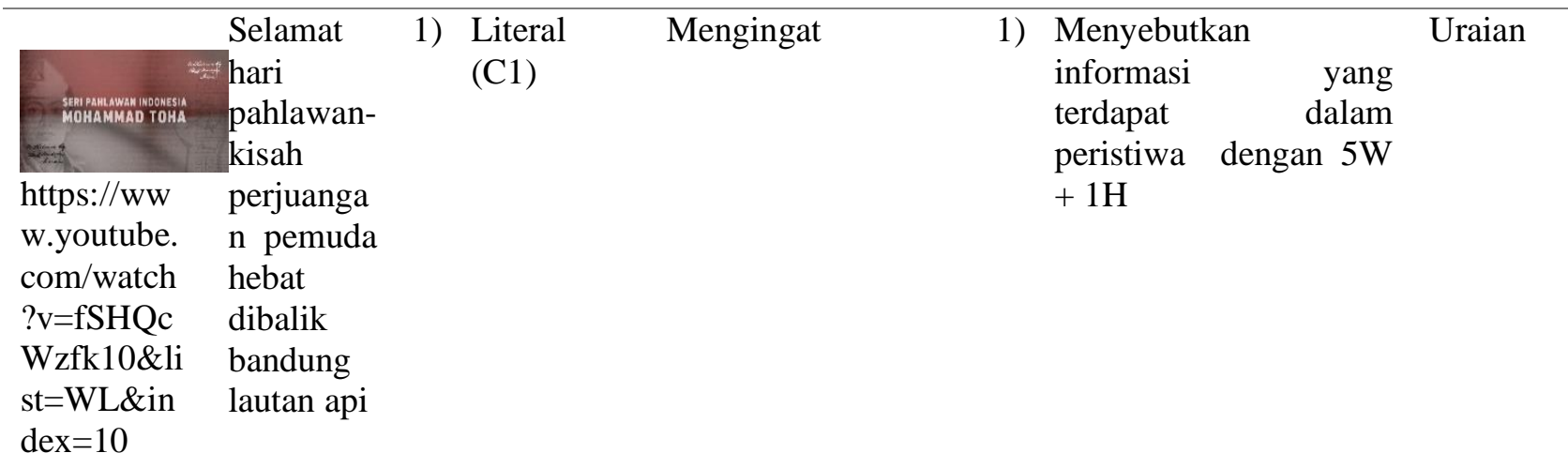

\begin{tabular}{llll}
\hline 2) Inferensial & Memahami, & 2) & Menceritakan kembali Uraian \\
& peristiwa tersebut \\
Interpretati & Mengaplikasikan & dengan bahasa mu \\
$\mathrm{f}$ & & sendiri secara tertulis \\
$(\mathrm{C} 2, \mathrm{C} 3)$ & & 3) & Mengemukakan pesan \\
& moral yang anda \\
& & dapatkan dari peristiwa \\
& & tersebut
\end{tabular}

\begin{tabular}{lll}
\hline 3) $\begin{array}{l}\text { Kritis } \\
(\mathrm{C} 4, \mathrm{C} 5)\end{array}$ & $\begin{array}{l}\text { Menganalisis, } \\
\text { Mengevaluasi }\end{array}$ & 4) $\begin{array}{l}\text { Membuat sketsa wajah } \\
\text { tokoh yang dikagumi }\end{array}$
\end{tabular}


dan menuliskan bagian menarik dari peristiwa

5) Membuat suatu

diagram lingkaran

yang berisi

perbandingan sifat

yang dimiliki tokoh

utama dengan anda

Table 3. Kisi-kisi Soal Tes Kemampuan Membbaca Pemahaman Dalam Pembbelajaran Multiliterasi Siswa SDN 3 Nagri Kaler

\begin{tabular}{|c|c|c|c|c|c|c|}
\hline \multirow[t]{2}{*}{ No } & \multirow{2}{*}{$\begin{array}{l}\text { Domain } \\
\text { kognitif }\end{array}$} & \multirow[t]{2}{*}{ Jenis pengetahuan dan Indikator } & \multicolumn{3}{|c|}{ Tingkat kesukaran } & \multirow[t]{2}{*}{ Jumlah butir } \\
\hline & & & sukar & sedang & mudah & \\
\hline 1 & $\mathrm{C} 1$ & Pemahaman literal $(5 \mathrm{~W}+1 \mathrm{H})$ & & & 6 & 6 \\
\hline 2 & $\mathrm{C} 2, \mathrm{C} 3$ & $\begin{array}{l}\text { Pemahaman Inferensial/Interpretatif } \\
\text { (menceritakan kembali peristiwa } \\
\text { dan nilai moral yang dapat } \\
\text { diteladani secara tertulis) }\end{array}$ & & 1 & & 1 \\
\hline 3 & $\mathrm{C} 4, \mathrm{C} 5$ & $\begin{array}{l}\text { Pemahaman Kritis (mengambarkan } \\
\text { sketsa wajah tokoh yang dikagumi } \\
\text { dan menuliskan bagian peristiwa } \\
\text { yang menarik kemudian membuat } \\
\text { diagram lingkaran yang berisi } \\
\text { perbandingan sifat tokoh pahlawan } \\
\text { dengan anda) }\end{array}$ & & 2 & & 2 \\
\hline 4 & C6 & $\begin{array}{l}\text { Pemahaman Kreatif (Membuat } \\
\text { desain mind mapping yang berisi } \\
\text { informasi dari peristiwa dengan } \\
\text { penyajian yang menarik dan bahasa } \\
\text { Indonesia yang baik dan benar). }\end{array}$ & 1 & & & 1 \\
\hline Jum & utir & & 1 & 3 & 6 & 10 \\
\hline
\end{tabular}

Nilai Akhir $=$

Skor yang diperoleh

\section{Skor total}

Skala dapat menggunakan 4, 10 dan 100 (Abidin, 2016)

Tabel 4. Penafsiran Skor Siswa

\begin{tabular}{lll}
\hline Sangat baik & $3,20-4.00$ & $80-100$ \\
\hline Baik & $2,80-3,19$ & $70-69$ \\
\hline Cukup & $2,40-2,79$ & $60-69$ \\
\hline Kurang & Kurang dari 2,40 & Kurang dari $60 \%$ \\
\hline
\end{tabular}

Tabel 5. Kisi-Kisi Jenis Pertanyaan Wawancara(Sugiyono, 2016)

\begin{tabular}{llllll}
\hline No. Jenis Pertanyaan & $\begin{array}{l}\text { Jumlah } \\
\text { butir } \\
\text { pertanyaan } \\
\text { siswa }\end{array}$ & $\begin{array}{l}\text { Jumlah butir } \\
\text { pertanyaan } \\
\text { orang tua siswa }\end{array}$ & $\begin{array}{l}\text { Jumlah } \\
\text { butir } \\
\text { pertanyaan } \\
\text { wali kelas }\end{array}$ & $\begin{array}{l}\text { Jumlah } \\
\text { butir } \\
\text { pertanyaan } \\
\text { kepala } \\
\text { sekolah }\end{array}$ \\
\hline 1. & Latar belakang dan demografi & 3 & 3 & 3 & 1 \\
\hline
\end{tabular}


2293 Analisis Kemampuan Membaca Pemahaman dalam Pembelajaran Multiliterasi Siswa Sekolah Dasar Nova Mira Rizky Wulandari, Neneng Sri Wulan, D Wahyudin

DOI: https://doi.org/10.31004/edukatif.v3i5.833

\begin{tabular}{llllll}
\hline 2. & Pengalaman & 10 & 4 & 6 & 1 \\
\hline 3. & Pendapat & 3 & 1 & 3 & 2 \\
\hline 4. & Indera & 2 & 2 & 2 & 2 \\
\hline 5. & Perasaan & 1 & 2 & 1 & 1 \\
\hline 6. & Pengetahuan & 7 & 2 & 2 & 5 \\
\hline Total butir pertanyaan wawancara & 26 & 14 & 17 & 12
\end{tabular}

Dokumentasi sebagai bukti peristiwa yang telah dilalui Bogdan dalam (Sugiyono, 2016)dan analisis data Miles and Huberman dalam (Sugiyono, 2016) meliputi: 1) reduksi data, 2) display data atau penyajian data, 3) Penarikan kesimpulan atau verifikasi data.

\section{HASIL DAN PEMBAHASAN PENELITIAN}

Tabel 6. Hasil Temuan Data Lima Subjek Siswa Penelitian

\begin{tabular}{lllllll}
\hline No & Nama/ Inisial & Usia & Jenis Kelamin & Alamat & \\
\hline 1 & DF & 11 tahun & Laki-laki & $\begin{array}{l}\text { Gang Soka 2 RT.46 RW.05 } \\
\text { No.132 A }\end{array}$ \\
\hline 2 & OZ & 11 tahun & Laki-laki & $\begin{array}{l}\text { Gang Soka 2 RT.47 RW.05 } \\
\text { Kebon Kolot }\end{array}$ \\
\hline 3 & AI & 11 tahun & Perempuan & Gang Kenanga 1 RT. 43 RW.05 \\
\hline 4 & AN & 12 tahun & Perempuan & $\begin{array}{l}\text { Panorama Blok M 2 RT.50 } \\
\text { RW.12 No.9 }\end{array}$ \\
\hline 5 & MR & 12 tahun & Perempuan & $\begin{array}{l}\text { Panorama Blok I 1 RT. 48 RW. } \\
12 \text { No.11 }\end{array}$ \\
\hline
\end{tabular}

Tabel 7. Perolehan Skor Tes Kemampuan Membaca Pemahaman dalam Multiliterasi DF

\begin{tabular}{|c|c|c|c|c|c|c|c|c|c|c|c|c|}
\hline \multirow{2}{*}{$\begin{array}{l}\text { Skor Indikator } \\
\text { kemampuan } \\
\text { pemahaman }\end{array}$} & \multicolumn{10}{|c|}{ No soal } & \multirow{2}{*}{$\begin{array}{l}\text { Total } \\
\text { Skor }\end{array}$} & \multirow[t]{2}{*}{ Nilai Akhir Indikator } \\
\hline & 1 & 2 & 3 & 4 & 5 & 6 & 7 & 8 & 9 & 10 & & \\
\hline Literal (C1) & 2 & 2 & 4 & 2 & 2 & 2 & & & & & 14 & $14 / 24 \times 100=58,3 \%$ \\
\hline $\begin{array}{l}\text { Inferensial } \\
(\mathrm{C} 2, \mathrm{C} 3)\end{array}$ & & & & & & & 2 & & & & 2 & $2 / 4 \times 100=50 \%$ \\
\hline Kritis $(\mathrm{C} 4, \mathrm{C} 5)$ & & & & & & & & 2 & 3 & & 5 & $5 / 8 \times 100=62.5 \%$ \\
\hline Kreatif (C6) & & & & & & & & & & 2 & 2 & $2 / 4 \times 100=50 \%$ \\
\hline $\begin{array}{l}\text { Nilai Akhir Kem } \\
\text { Multiliterasi DF }\end{array}$ & $\mathrm{p}$ & & $m$ & & & 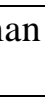 & 1 & D & & $\operatorname{aran}$ & 23 & $23 / 40 \times 100=57,5 \%$ \\
\hline
\end{tabular}

Tabel 8. Perolehan skor tes kemampuan membaca pemahaman dalam multiliterasi OZ

\begin{tabular}{|c|c|c|c|c|c|c|c|c|c|c|c|}
\hline \multirow{2}{*}{$\begin{array}{l}\text { Skor Indikator } \\
\text { kemampuan } \\
\text { pemahaman }\end{array}$} & \multicolumn{9}{|c|}{ No soal } & \multirow{2}{*}{$\begin{array}{l}\text { Total } \\
\text { Skor }\end{array}$} & \multirow{2}{*}{$\begin{array}{l}\text { Nilai } \\
\text { Indikator }\end{array}$} \\
\hline & 1 & 2 & 3 & 4 & 5 & 6 & 7 & 8 & 910 & & \\
\hline (C1) Literal & 2 & 2 & 2 & 2 & 2 & 2 & & & & 12 & $\begin{array}{l}12 / 24 \times 100= \\
50 \%\end{array}$ \\
\hline $\begin{array}{l}(\mathrm{C} 2, \mathrm{C} 3) \\
\text { Inferensial }\end{array}$ & & & & & & & 2 & & & 2 & $2 / 4 \times 100=50 \%$ \\
\hline$(\mathrm{C} 4, \mathrm{C} 5)$ Kritis & & & & & & & & 2 & 3 & 5 & $5 / 8 \times 100=62,5 \%$ \\
\hline (C6) Kreatif & & & & & & & & & 2 & 2 & $2 / 4 \times 100=50 \%$ \\
\hline
\end{tabular}


2294 Analisis Kemampuan Membaca Pemahaman dalam Pembelajaran Multiliterasi Siswa Sekolah Dasar Nova Mira Rizky Wulandari, Neneng Sri Wulan, D Wahyudin

DOI: https://doi.org/10.31004/edukatif.v3i5.833

Nilai Akhir Kemampuan Membaca Peahaman dalam $21 \quad 21 / 40$ x $100=52,5 \%$

Pembelajaran Multiliterasi OZ

Tabel 9. Perolehan skor tes kemampuan membaca pemahaman dalam multiliterasi AI

\begin{tabular}{|c|c|c|c|c|c|c|c|c|c|c|c|}
\hline \multirow{2}{*}{$\begin{array}{l}\text { Skor Indikator } \\
\text { kemampuan } \\
\text { pemahaman }\end{array}$} & \multicolumn{9}{|c|}{ No soal } & \multirow{2}{*}{$\begin{array}{l}\text { Total } \\
\text { Skor }\end{array}$} & \multirow{2}{*}{$\begin{array}{ll}\text { Nilai } & \text { Akhir } \\
\text { Indikator }\end{array}$} \\
\hline & 1 & 2 & 3 & 4 & 5 & 6 & 7 & 8 & 910 & & \\
\hline (C1) Literal & 2 & 2 & 4 & 2 & 1 & 2 & & & & 13 & $\begin{array}{l}13 / 24 \times 100= \\
54,16 \%\end{array}$ \\
\hline $\begin{array}{l}(\mathrm{C} 2, \mathrm{C} 3) \\
\text { Inferensial }\end{array}$ & & & & & & & 1 & & & 1 & $1 / 4 \times 100=25 \%$ \\
\hline$(\mathrm{C} 4, \mathrm{C} 5)$ Kritis & & & & & & & & 2 & 1 & 3 & $3 / 8 \times 100=37,5 \%$ \\
\hline (C6) Kreatif & & & & & & & & & 2 & 2 & $2 / 4 \times 100=50 \%$ \\
\hline $\begin{array}{l}\text { Nilai Akhir } \\
\text { Pembelajaran } \mathrm{Mu}\end{array}$ & $\begin{array}{l}\text { Kem } \\
\text { tilit }\end{array}$ & rasi & & & l & & & & dalam & 19 & $19 / 40 \times 100=47,5 \%$ \\
\hline
\end{tabular}

Tabel 10. Perolehan skor tes kemampuan membaca pemahaman dalam multiliterasi AN

\begin{tabular}{|c|c|c|c|c|c|c|c|c|c|c|c|c|}
\hline \multirow{2}{*}{$\begin{array}{l}\text { Skor } \\
\text { Indikator } \\
\text { kemampuan } \\
\text { pemahaman }\end{array}$} & \multicolumn{10}{|c|}{ No soal } & \multirow{2}{*}{$\begin{array}{l}\text { Total } \\
\text { Skor }\end{array}$} & \multirow{2}{*}{$\begin{array}{ll}\text { Nilai } & \text { Akhir }\end{array}$} \\
\hline & 1 & 2 & 3 & 4 & 5 & 6 & 7 & 8 & 9 & 10 & & \\
\hline (C1) Literal & 2 & 2 & 4 & 2 & 2 & 1 & & & & & 13 & $\begin{array}{l}13 / 24 \times 100= \\
54,16 \%\end{array}$ \\
\hline $\begin{array}{l}(\mathrm{C} 2, \mathrm{C} 3) \\
\text { Inferensial }\end{array}$ & & & & & & & 1 & & & & 1 & $1 / 4 \times 100=25 \%$ \\
\hline$(\mathrm{C} 4, \mathrm{C} 5)$ Kritis & & & & & & & & 2 & 3 & & 5 & $5 / 8 \times 100=62,5 \%$ \\
\hline (C6) Kreatif & & & & & & & & & & 2 & 2 & $2 / 4 \times 100=50 \%$ \\
\hline $\begin{array}{l}\text { Nilai Akhir Ke } \\
\text { Multiliterasi A }\end{array}$ & & an & $\boldsymbol{U}$ & aca & $\mathrm{ec}$ & & & & & aran & 21 & $\begin{array}{l}21 / 40 \times 100= \\
52,5 \%\end{array}$ \\
\hline
\end{tabular}

Tabel 11. Perolehan skor tes kemampuan membaca pemahaman dalam multiliterasi MR

\begin{tabular}{|c|c|c|c|c|c|c|c|c|c|c|c|}
\hline \multirow{2}{*}{$\begin{array}{c}\text { Skor } \\
\text { Indikator } \\
\text { kemampuan } \\
\text { pemahaman }\end{array}$} & \multicolumn{9}{|c|}{ No soal } & \multirow{2}{*}{$\begin{array}{l}\text { Total } \\
\text { Skor }\end{array}$} & \multirow{2}{*}{$\begin{array}{l}\text { Nilai Akhir } \\
\text { Indikator }\end{array}$} \\
\hline & 1 & 2 & 3 & 4 & 5 & 6 & 7 & 8 & 10 & & \\
\hline (C1) Literal & 2 & 2 & 2 & 2 & 1 & 1 & & & & 10 & $\begin{array}{c}10 / 24 \times 100= \\
41,6 \%\end{array}$ \\
\hline $\begin{array}{l}(\mathrm{C} 2, \mathrm{C} 3) \\
\text { Inferensial }\end{array}$ & & & & & & & 1 & & & 1 & $1 / 4 \times 100=25 \%$ \\
\hline $\begin{array}{l}(\mathrm{C} 4, \mathrm{C} 5) \\
\text { Kritis } \\
\end{array}$ & & & & & & & & 2 & 3 & 5 & $6 / 8 \times 100=62,5 \%$ \\
\hline (C6) Kreatif & & & & & & & & & 2 & 2 & $2 / 4 \times 100=50 \%$ \\
\hline $\begin{array}{l}\text { Nilai Akhir Ke } \\
\text { Multiliterasi N }\end{array}$ & & & & & & & & & belajaran & 18 & $18 / 40 \times 100=45 \%$ \\
\hline
\end{tabular}

Tabel 12. Pembahasan hasil tes kemampuan membaca pemahaman dalam pembelajaran multiliterasi siswa SDN 3 Nagri Kaler

\begin{tabular}{lllllllll}
\hline Indikator $\begin{array}{l}\text { kemampuan } \\
\text { membaca pemahaman dalam } \\
\text { pembelajaran multiliterasi }\end{array}$ & Skor & DF & OZ & AI & AN & MR & $\begin{array}{l}\text { Nilai } \\
\text { Indikator }\end{array}$ & Akhir \\
\hline
\end{tabular}


2295 Analisis Kemampuan Membaca Pemahaman dalam Pembelajaran Multiliterasi Siswa Sekolah Dasar Nova Mira Rizky Wulandari, Neneng Sri Wulan, D Wahyudin

DOI: https://doi.org/10.31004/edukatif.v3i5.833

\begin{tabular}{lllllll}
\hline Literal (CI) & $58.3 \%$ & $50 \%$ & $54,1 \%$ & $54,1 \%$ & $41,6 \%$ & $51,6 \%$ \\
\hline Inferensial (C2,C3) & $50 \%$ & $50 \%$ & $25 \%$ & $25 \%$ & $25 \%$ & $35 \%$ \\
\hline Kritis (C4,C5) & $62,5 \%$ & $62,5 \%$ & $37,5 \%$ & $62,5 \%$ & $62,5 \%$ & $60 \%$ \\
\hline Kreatif (C6) & $50 \%$ & $50 \%$ & $50 \%$ & $50 \%$ & $50 \%$ & $50 \%$ \\
\hline $\begin{array}{l}\text { Nilai Akhir Kemampuan } \\
\text { Membaca Pemahaman dalam }\end{array}$ & $57,5 \%$ & $52,5 \%$ & $47,5 \%$ & $52,5 \%$ & $45 \%$ & $51 \%$ \\
Pembelajaran Multiliterasi & & & & & & \\
\hline
\end{tabular}

Berdasarkan hasil tes kemampuan membaca pemahaman dalam pembelajaran multiliterasi kelima siswa SDN 3 Nagri Kaler secara keseluruhan adalah 51\% termasuk kategori kurang dari 60\%, skor rendah diperoleh subjek dengan inisial MR yaitu 45(Skala 100) dan AI yaitu 47,5 (Skala 100). Untuk skor tertinggi diperoleh subjek dengan inisial DF 57,5 (Skala 100). Serta skor tengah diperoleh subjek dengan inisial OZ dan AN yaitu 52,5 (Skala 100). Sehingga pembelajaran multiliterasi yang diterima oleh kelima siswa dinyatakan belum sesuai dengan pendapat Iyer dan Luke dalam (Abidin et al., 2018) yang menyatakan apabila peserta didik telah mengikuti pembelajaran multilitearsi akan menuai perkembangan pemahaman yang tinggi. Karena kelima subjek memiliki kategori kurang dalam kemampuan literal (C1) yang merupakan tingkatan dasar yang paling mudah menurut Burns dan Roes dalam (Dalman, 2021) Kelima siswa memperoleh skor paling kecil pada kemampuan inferensial (C2,C3) menurut Otto dan Chester dalam Tarigan dalam (Dalman, 2021) seharusnya siswa kelas 5-6 SD wajib mencapai pemahaman interpretative dalam tingkat siswa mampu mempertimbangkan dan memikirkan pemikiran penulis, Hal tersebut menandakan kelima siswa tersebut belum memiliki kemampuan berpikir lebih tinggi karena jawaban dalam kategori interpretatif terkait dengan jawaban yang tidak ada dalam teks melainkan pendapat dari peserta didik itu sendiri Burns, Rubin (1982) dalam (Fauziah, 2013) Selanjutnya dalam kemampuan kritis (C4,C5) Menurut syafi'i 1993 dalam (Rahim, 2018) integrasi pengalaman dan pemahaman yang baru untuk mengiktisar kemudian menilai hasil bacaan tersebut. Nurhadi (2004) dalam (Dalman, 2021) terdapat berbagai kemampuan dalam meningkatkan sikap kritis peserta didik berupa kemampuan mengingat dan mengenali, tokoh-tokoh cerita beserta sifatnya, menyatakan kembali perbandingan, karakter tokoh, dan terdapat empat siswa dengan inisial (DF,OZ,AN,MR) telah masuk kategori cukup dan satu siswa dengan inisial (AI) yang berkategori kurang dalam membuat sketsa wajah tokoh yang dikagumi dan menuliskan bagian menarik dari peristiwa kemudian membuat suatu diagram venn yang berisi perbandingan sifat tokoh dan dirinya, dalam kemampuan kreatif (C6) yang seharusnya kelima siswa telah mampu membaca kreatif di kelas 5-6 SD Otto dan Chester (1976) dalam Tarigan (1984) dalam (Dalman, 2021) dengan membuat suatu karya, namun hasil tes menyatakan kelima siswa termasuk kategori kurang dalam membuat mind mapping.

Hasil wawancara peneliti dengan kelima subjek siswa menyatakan membaca dengan video lebih menyenangkan, memperoleh pengetahuan baru tentang seri kisah pahlawan Mohammad Toha dalam peristiwa Bandung Lautan Api. Sujek sudah menguasai penggunaan teknologi dalam pencarian kata-kata sulit melalui google. Namun kelima subjek masih sulit untuk memahami tentang nama tokoh, tahun, dan nilai moral yang sesuai dengan isi video yang ditampilkan. Berbagai faktor kendala kemampuan membaca pemahaman ditemukan dalam hasil wawancara yang dilakukan peneliti dengan siswa, orang tua, wali kelas dan kepala sekolah, Peneliti menemukan solusi hambatan kemampuan membaca pemahaman dari hasil wawancara peneliti dengan Wali kelas V dan Kepala sekolah SDN 3 Nagri Kaler. Berdasarkan hasil tes dan wawancara tersebut pembelajaran multiliterasi tidak sepenuhnya dapat meningkatkan kemampuan membaca pemahaman seperti hasil penelitian terdahulu oleh (Ristika, 2019), (Dafit, 2017) dan (Susilo \& Garnisya, 2018) karena masih terdapat faktor kendala yang perlu diselesaikan dengan solusi yang telah ditemukan oleh peneliti.

Adanya batasan pada pembahasan hasil penelitian ini untuk menjamin keberhasilan peneliti pencapaian tujuan penelitian yaitu hanya untuk mengetahui bagaimana kemampuan membaca pemahaman dalam pembelajaran multiliterasi siswa SDN 3 Nagri Kaler, apa faktor kendala kemampuan membaca pemahaman 
2296 Analisis Kemampuan Membaca Pemahaman dalam Pembelajaran Multiliterasi Siswa Sekolah Dasar Nova Mira Rizky Wulandari, Neneng Sri Wulan, D Wahyudin

DOI: https://doi.org/10.31004/edukatif.v3i5.833

dalam pembelajaran multiliterasi siswa SDN 3 Nagri Kaler, bagaimana mengatasi kendala kemampuan membaca pemahaman dalam pembelajaran multiliterasi siswa SDN 3 Nagri Kaler.

Dalam perkembangan ilmu pendidikan penelitian ini sangat bermanfaat secara teoritis sebagai sumber referensi dalam kemampuan membaca pemahaman dalam pembelajaran multiliterasi siswa sekolah dasar, secara praktis bermanfaat untuk siswa sehingga dapat memicu respon positif peserta didik sebagai generasi era digital sehingga menuai kemampuan membaca pemahaman dalam pembelajaran multiliterasi siswa sekolah dasar, untuk guru memicu pemahaman tenaga pendidik dalam mengemas materi bahasa Indonesia tentang kemampuan membaca pemahaman dalam pembelajaran multiliterasi siswa sekolah dasar, untuk peneliti selanjutnya dapat melatih pemahaman kemampuan membaca pemahaman dalam pembelajaran multiliterasi siswa sekolah dasar lebih mendalam, dan untuk satuan pendidikan penelitian ini diharapkan dapat memberikan kontribusi positif dalam meningkatkan kualitas pendidikan Indonesia khususnya dalam kemampuan membaca pemahaman dalam pembelajaran multiliterasi siswa sekolah dasar.

\section{KESIMPULAN}

Kemampuan membaca pemahaman dalam pembelajaran multiliterasi siswa kelas V SDN 3 Nagri Kaler kurang dari $60 \%$ pada pemahaman literal, inferensial dan kreatif. Empat siswa berkategori cukup pada pemahaman kritis yaitu $>60 \%$. Faktor kendala yang terjadi 1) Ekonomi keluarga menengah kebawah, 2) Kurangnya sarana membaca, 3) Kurangnya pembiasaan membaca, 4) Kurangnya kesiapan metode dan strategi guru kreatif dalam pembelajaran multiliterasi, 5) Keberagaman karakteristik siswa, 6) Kesulitan komunikasi pihak sekolah dengan orang tua. Solusi mengatasi kendala 1) Kerjasama orang tua, siswa dan pihak sekolah dalam memonitor dan memberi sarana bacaan yang siswa minati, 2) Penyediaan waktu bimbingan secara berkala, 3) Memperkuat komunikasi, 4) Kemauan guru berlatih mengelola pembelajaran multiliterasi secara berkesinambungan. Peneliti merekomendasikan kepada guru kelas untuk aktif mengelola metode dan strategi untuk meningkatkan kemampuan membaca pemahaman dalam pembelajaran multiliterasi, kepada siswa tetap fokus dan disiplin dalam kegiatan membaca pemahaman dalam pembelajaran multiliterasi, kepada orang tua seyogyanya mampu memanajemen waktu memonitor anak di rumah, dalam kesibukan apapun dan rekomendasi kepada peneliti selanjutnya untuk mengkaji kemampuan membaca pemahaman dalam pembelajaran multiliterasi siswa kelas V SD dengan jumlah subjek lebih banyak dan kolaborasi berbagai metode serta strategi pembelajaran, sehingga kajian semakin luas dan mendalam untuk menemukan berbagai hambatan dan solusi lainnya.

\section{DAFTAR PUSTAKA}

Abidin, Y. (2012). Pembelajaran Membaca Berbasis Pendidikan Karakter (N. F. Atif (Ed.); 2nd Ed.). Bandung: PT Refika Aditama.

Abidin, Y. (2015). Pembelajaran Multiliterasi Sebuah Jawaban Atas Tantangan Pendidikan Abad 21 Dalam Konteks Keindonesiaan (D. Sumayyah (Ed.); 1st Ed.). Bandung: PT Refika Aditama.

Abidin, Y. (2016). Revitalisasi Penilaian Pembelajaran Dalam Konteks Pendidikan Multiliterasi Abad Ke-21 (N. F. Atif (Ed.); 1st Ed.). Bandung: PT Refika Aditama.

Abidin, Y., Mulyati, T., \& Yunansah, H. (2018). Pembelajaran Literasi Strategi Meningkatkan Kemampuan Literasi Matematika, Sains, Membaca, Dan Menulis (Y. N. I. Sari (Ed.); 2nd Ed.). Jakarta: Bumi Aksara.

Aprinawati, I. (2018). Penggunaan Model Peta Pikiran (Mind Mapping) Untuk Meningkatkan Pemahaman Membaca Wacana Siswa Sekolah Dasar. Jurnal Basicedu, 2(1), 140-147. Https://Doi.Org/10.31004/Basicedu.V2i1.35 
2297 Analisis Kemampuan Membaca Pemahaman dalam Pembelajaran Multiliterasi Siswa Sekolah Dasar Nova Mira Rizky Wulandari, Neneng Sri Wulan, D Wahyudin

DOI: https://doi.org/10.31004/edukatif.v3i5.833

Bahtiar, H. (2016). Fakultas Bahasa Dan Seni Universitas Negeri Semarang 2016. In Unnes.

Chrismawati, M., Septiana, I., \& Purbiyanti, E. D. (2021). Edukatif: Jurnal Ilmu Pendidikan Peningkatan Hasil Belajar Melalui Model Flipped Classroom Berbantuan Media Power Point Dan Audio Visual Di Sekolah Dasar. 3(5), 1928-1934.

Dafit, F. (2017). Implementasi Model Multiliterasi Pada Proses Pembelajaran Membaca Pemahaman Siswa Kelas Iv Sekolah Dasar. Jurnal Sekolah, 1(2), 53-59.

Dalman. (2021). Keterampilan Membaca (3rd Ed.). Jakarta: Rajawai Pers.

Danim, S. (2017). Perkembangan Peserta Didik (5th Ed.). Bandung: Afabeta.

Fauzi, M. R. (2020). Analisis Kemampuan Membaca Pemahman Siswa Sekolah Dasar Kelas Tinggi Dengan Menentukan Ide Pokok Paragraf Melalui Metode Concentrated Language Encounter. 2614, 03(04), 147161.

Fauziah, S. (2013). Kemampuan Membaca Pemahaman Literal Dan Interpretatif Melalui Pendekatan Konstruktivisme. Kemampuan Membaca Pemahaman, 6(2).

Fuady, A., Sumarwati, \& Mulyono, S. (2012). Pembuatan Peta Semantik Pada Kegiatan Prabaca Untuk Meningkatkan Kemampuan Memahami Bacaan Siswa Sekolah Menengah. Journal Of Chemical Information And Modeling, 1(1), 1-24.

Haryoko, S. (2009). Efektivitas Pemanfaatan Media Audio-Visual Sebagai Alternatif Optimalisasi Model

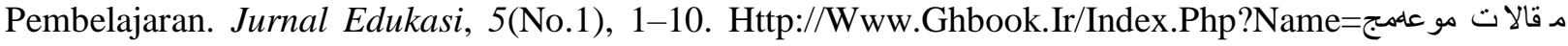

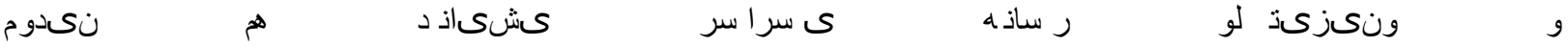
\&Option=Com_Dbook\&Task=Readonline\&Book_Id=13629\&Page=108\&Chkhashk=03C7 06812F\&Itemid=218\&Lang=Fa\&Tmpl=Component

Hasan, A. (2015). Peningkatan Kemampuan Membaca Nyaring Melalui Metode Latihan Pada Siswa Kelas IV SDN Salunggadue. Jurnal Kreatif Tadulako Online, 5(6), 246-257. Http://Jurnal.Untad.Ac.Id/Jurnal/Index.Php/JKTO/Article/View/3878

Iswara, P. D. (2016). Pengembangan Materi Ajar Dan Evaluasi Pada Keterampilan Mendengarkan Dan Membaca. Mimbar Sekolah Dasar, 3(1), 89-97. Https://Doi.Org/10.17509/Mimbar-Sd.V3i1.2359

Khairil, A. (2020). Arah Dan Pembelajaran Bahasa Dan Sastra Indonesia Pada Era Revolusi Industri 4.0 (U. Shafwan Hadi, H. Amir, K. Rahmad, Sutikno, \& H. Tiflatul (Eds.); 1st Ed.). Medan: Pustaka Diksi. Https://Www.Google.Co.Id/Books/Edition/Arah_Pembelajaran_Bahasa_Dan_Sastra_Indo/Skrsdwaaqbaj $? \mathrm{Hl}=\mathrm{Id} \& \mathrm{Gbpv}=1 \& \mathrm{Dq}=$ Multiliterasi\&Pg=PA121\&Printsec $=$ Frontcover

Madyawati, L. (2017). Strategi Pengembangan Bahasa Pada Anak (Rendy (Ed.); 2nd Ed.). Jakarta: KENCANA.

Https://Books.Google.Co.Id/Books?Id=R-

Padwaaqbaj\&Printsec=Frontcover \&Dq=Buku+Depdiknas $+2007 \& H \mathrm{H}=\mathrm{Id} \& \mathrm{Sa}=\mathrm{X} \&$ Ved $=2$ ahukewiqnogz8 1_Uahwm4jgghqmhdiu4hhc7btagegqibhah\#V=Onepage \&Q=Buku Depdiknas 2007\&F=False

Mariyaningsih, N., \& Hidayai, M. (2018). Bukan Kelas Biasa: Teori Dan Praktik Berbagai Model Dam Metode Pembelajaan Di Kelas-Kelas Inspiratif (A. K. Putra (Ed.); 1st Ed.). Surakata: CV Kekata Group.

Marzoan. (2020). Studi Eksploratif Persepsi Guru Terhadap Kebijakan Belajar Dari Rumah Pada Masa Pandemi Covid-19. Jurnal Ilmiah Mandala Education, 6(2), 200-207. Http://Ejournal.Mandalanursa.Org/Index.Php/JIME/Index

OEDC. (2003). Literacy Skills For The World Of Tomorrow Further Results From PISA 2000 Executive. Https://Www.Oecd.Org/Education/School/2960581.Pdf

Pratama, V. A. (2015). Peningkatan Membaca Pemahaman Dengan Menggunakan Metode Individualized Schema-Based Learning Dan Transactional Learning Bagi Siswa Sekolah Dasar. 1979, 978-979.

Pulungan, M. (2015). Kajian Evaluasi Tenaga Pendidikan Dalam Rangka Peningkatan Kualitas Pendidikan Di 
2298 Analisis Kemampuan Membaca Pemahaman dalam Pembelajaran Multiliterasi Siswa Sekolah Dasar Nova Mira Rizky Wulandari, Neneng Sri Wulan, D Wahyudin

DOI: https://doi.org/10.31004/edukatif.v3i5.833

Kutai Kartanegara Provinsi Kaltim. Jurnal Bina Praja, 07(01), 51-62. Https://Doi.Org/10.21787/Jbp.07.2015.51-62

Purwanto, A., Pramono, R., Asbari, M., Santoso, P. B., Wijayanti, L. M., Choi, C. H., \& Putri, R. S. (2020). Studi Eksploratif Dampak Pandemi COVID-19 Terhadap Proses Pembelajaran Online Di Sekolah Dasar. Edupsycouns: Journal Of Education, Psychology And Counseling, 2(1), 1-12. Https://Ummaspul.EJournal.Id/Edupsycouns/Article/View/397

Rahim, F. (2018). Pengajaran Membaca Di Sekolah Dasar (5th Ed.). Jakarta: Bumi Aksara.

Ristika. (2019). Model Pembelajaran Multiliterasi Pada. 3(2), 149-154.

Rukajat, A. (2018). Pendekatan Penelitian Kualitatif Qualitative Research Approach (D. Novidiantoko \& C. M. Sartono (Eds.); 1st Ed.). Yogyakarta: Deepublish Griup Penerbit CV Budi Utama. Https://Www.Google.Co.Id/Books/Edition/Pendekatan_Penelitian_Kualitatif_Qualita/Qy1qdwaaqbaj?Hl $=\mathrm{Id} \& \mathrm{Gbpv}=1 \& \mathrm{Dq}=$ Pendekatan + Studi + Kasus + Buku\&Printsec $=$ Frontcover

Saleh, A. R. (2006). Peranan Teknologi Informasi Dalam Meningkatkan Kegemaran Membaca Dan Menulis Masyarakat. Jurnal Pustakawan Indonesia, 6(May), 1.

Salim, \& Haidir. (2019). Penelitian Pendidikan Metode, Pendekatan, Dan Jenis (I. S. Azhar (Ed.); 1st Ed.). Jakarta: Kencana (Divisi Dari Group). Https://Www.Google.Co.Id/Books/Edition/Penelitian_Pendidikan_Metode_Pendekatan/2fq1dwaaqbaj? $\mathrm{Hl}=\mathrm{Id} \& \mathrm{Gbpv}=1 \& \mathrm{Dq}=$ Pendekatan+Studi + Kasus + Buku $\&$ Printsec=Frontcover

Saputro, K. A., Sari, C. K., \& Winarsi, S. W. (2021). Edukatif: Jurnal Ilmu Pendidikan Peningkatan Keterampilan Membaca Dengan Menggunakan Media Audio Visual Di Sekolah Dasar. 3(5), 19101917.

Saripudin, Spd, \& MT. (2019). Pedoman Penulisan Karya Ilmiah UPI Tahun 2019 (P. 89).

Subroto, G. (2015). Peran Dan Tantangan Tik ( Internet ) Dalam Pembangunan Pendidikan Indonesia The Role And Challenges Of Ict ( Internet ) In. Jurnal Teknodik, 19(3), 119-134.

Sugiyono. (2016). Metode Penelitian (Sugiyono (Ed.); 23rd Ed.). Bandung: Afabeta.

Susilo, S. V., \& Garnisya, G. R. (2018). Penerapan Model Multiliterasi Untuk Meningkatkan Kemampuan Membaca Pemahaman Siswa Sekolah Dasar. Jurnal Cakrawala Pendas, 4(2), 1-71. Https://Doi.Org/10.31949/Jcp.V4i2.1128

Untari, M. F. A., \& Saputra, A. A. (2016). Keefektifan Media Komik Terhadap Kemampuan Membaca Pemahaman Pada Siswa Kelas Iv Sd. Mimbar Sekolah Dasar, 3(1), 29-39. Https://Doi.Org/10.17509/Mimbar-Sd.V3i1.2354 